\title{
Palmar erythema in acute-on-chronic liver failure
}

\author{
Cheng-Maw Ho* and Po-Huang Lee \\ Department of Surgery, National Taiwan University Hospital, Taipei, Taiwan
}

\section{Case report}

A 48-year-old man, with Child A liver cirrhosis due to hepatitis B virus (HBV) infection, presented with acute onset of jaundice, conscious disturbance and palmar erythema (Figure 1) for a week. Serum levels of total bilirubin was $20.3 \mathrm{mg} / \mathrm{dL}$, ammonia $93 \mu \mathrm{mol} / \mathrm{L}$, international normalized ratio of prothrombin time 2.03 and $\alpha$-feto-protein 42.1 $\mathrm{ng} / \mathrm{mL}$, compatible with the course of acute-on-chronic liver failure. His serum HBV profiles of DNA, antibody for HBV surface and core antigens (anti-HBs, IgM-anti-HBc) were $1.36 \times 10^{6} \mathrm{IU} / \mathrm{mL}$, positive and positive, respectively. An incidental $3 \mathrm{~cm}$ hepatocellular carcinoma located at left lobe of liver was noted in contrast-enhanced abdominal tomography. He received entecavir $(0.5 \mathrm{mg})$ daily and waited for liver transplantation. The HCC became multiple (>3) and invaded the left portal vein despite of the temporary remission of jaundice and palmar erythema. Therefore, liver transplantation is no longer indicated. Liver regeneration could facilitate the growth of the present HCC or dormant micro-metastases. He passed away 1 year later because of cancer-related liver failure.

Palmar erythema is a non-specific and often overlooked sign, but it is a sensitive stigmata of chronic liver disease in combination with jaundice. Increased free estrogens, disordered hepatic metabolism of bradykinin and other vasoactive substances are associated with the

Copyright: $(02018$ Ho C. This is an open-access article distributed under the terms of the Creative Commons Attribution License, which permits unrestricted use, distribution, and reproduction in any medium, provided the original author and source are credited. sign development. However, it is reversible, as described in this case of acute-on-chronic liver failure, when liver regeneration restores liver function to a certain degree.

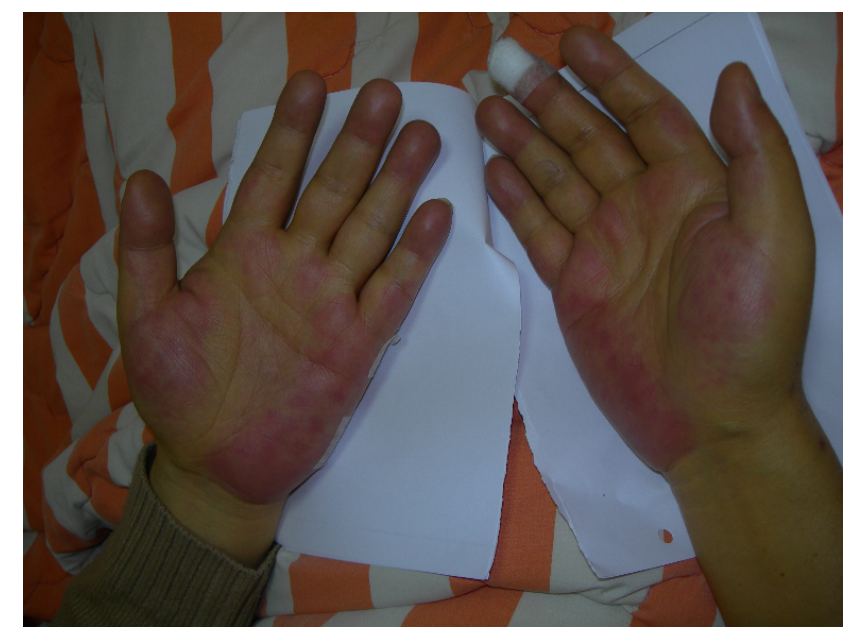

Figure 1. Palmar erythema in a patient of acute-on-chronic liver failure. Note the symmetric erythema involving the thenar and hypothenar eminences and the yellow hue of jaundice at hands
${ }^{\star}$ Correspondence to: Cheng-Maw Ho, MD, $\mathrm{PhD}$, Department of Surgery, National Taiwan University Hospital, No.7 Chung-Shan South Road, Taipei 100, Taiwan, Tel: +886-2-23123456, ext. 65914; Fax: +886-2-2356-8810; E-mail: miningho@ntu.edu.tw

Received: August 08, 2018; Accepted: August 17, 2018; Published: August 21, 2018 